\title{
Epidemiology of respiratory syncytial virus infection and its effect on children with heart disease in Hong Kong: a multicentre review
}

\author{
SH Lee *, KL Hon, WK Chiu, YW Ting, SY Lam
}

\section{A B S T R A C T}

Objectives: There is no guideline in Hong Kong regarding respiratory syncytial virus (RSV) immunoprophylaxis for children with heart disease because of a lack of local data on RSV infection. Therefore, this study evaluated the epidemiology and impact of RSV infection on children with heart disease in Hong Kong, with the goal of providing recommendations regarding RSV immunoprophylaxis.

Methods: This multicentre retrospective casecontrol study on paediatric RSV infection was conducted in four local regional hospitals from 2013 to 2015. The patients' demographic and clinical data were retrieved and analysed.

Results: There were 3538 RSV hospitalisations during the study period, and the mortality rate was $0.14 \%$. Some RSV seasonality was present in Hong Kong, primarily in spring and summer. Respiratory syncytial virus infection was positively correlated with relative humidity and negatively correlated with wind speed and atmospheric pressure. Patients with heart disease had a more severe outcome than those without, including longer median hospital stay (4 vs 2 days, $\mathrm{P}<0.001)$, higher complication rate $(28.6 \%$ vs $9.8 \%, \mathrm{P}<0.001)$, and higher rates of intensive care

This article was published on 9 Oct 2019 at www.hkmj.org.
(11.6\% vs $1.4 \%, \mathrm{P}<0.001)$ and mechanical ventilation (3.6\% vs $0.4 \%, P=0.003$ ). Complications in noncardiac patients included myocarditis and Kawasaki disease. Predictors of severe RSV infection in patients with heart disease were heart failure, pulmonary hypertension, and severe airway abnormalities associated with congenital heart disease.

Conclusions: Respiratory syncytial virus infection occurs mainly in spring and summer in Hong Kong, and is related to meteorological conditions. Respiratory syncytial virus infection poses a heavy disease burden on children with heart disease. A local guideline on RSV immunoprophylaxis for these children is therefore needed.

\section{Hong Kong Med J 2019;25:363-71 \\ https://doi.org/10.12809/hkmj197903}

${ }^{1}$ SH Lee *, MB, BS, FRCPCH

${ }^{2} \mathrm{KL}$ Hon, MB, BS, MD

${ }^{3}$ WK Chiu, MB, BS, FRCPCH

${ }^{4}$ YW Ting, MB, ChB, FHKAM (Paediatrics)

${ }^{4}$ SY Lam, MB, BS, FRCPCH

${ }^{1}$ Department of Paediatrics and Adolescent Medicine, Queen Elizabeth Hospital, Jordan, Hong Kong

Department of Paediatrics, The Chinese University of Hong Kong, Shatin, Hong Kong

${ }^{3}$ Department of Paediatrics and Adolescent Medicine, United Christian Hospital, Kwun Tong, Hong Kong

${ }^{4}$ Department of Paediatrics and Adolescent Medicine, Tuen Mun Hospital, Tuen Mun, Hong Kong

* Corresponding author: leeshm@ha.org.hk

New knowledge added by this study

- This study reviewed the epidemiology and impact of respiratory syncytial virus (RSV) infection on children with heart disease (HD) in Hong Kong.

- RSV infections are common in Hong Kong, and the incidence peaks from March to August; prevalence is greatest in children aged $<1$ year, and there is a mild male preponderance. Infection is favoured by high relative humidity, low wind speed, and low atmospheric pressure.

- HD, both congenital and acquired, is a distinct risk factor for severe RSV infection in terms of hospital length of stay, reinfection, complication, respiratory failure, and the requirements for intensive care unit care and mechanical ventilation.

Implications for clinical practice or polic

- A local guideline on RSV immunoprophylaxis is needed for children with HD.

- In Hong Kong, an RSV immunoprophylaxis scheme administered monthly for 5 months, beginning in the first year of life, should be considered in children with HD who exhibit any of the following severity predictors: heart failure, pulmonary hypertension, and severe airway abnormalities associated with congenital HD.

- The optimal timing for immunoprophylaxis may be during the local peak of infection, from March to August. 


\section{香港的呼吸道合胞病毒感染流行病學及其對心臟 病患兒的影響：多中心研究 \\ 李淑嫻、韓錦倫、趙華強、丁恩榮、林樹仁}

目的：由於香港缺乏心藏病患兒呼吸道合胞病毒 (RSV) 感染的數 據, 現時沒有針對心藏病患兒RSV免疫預防的指導方針。本研究評估 $R S V$ 感染的香港流行病學和對心藏病患兒的影響, 以提供RSV免疫預 防建議。

方法：這項針對兒科RSV感染的多中心回顧性病例對照研究於2013年 至2015年在香港四所區域醫院的兒科部門進行, 檢索並分析香港RSV 感染的流行病學和臨床數據。

結果：研究期間共 3538 宗RSV住院案例, 死亡率為 $0.14 \%$ 。在香 港RSV感染亦有輕微的季節性, 兒童RSV感染主要於春季和夏季發 生。RSV感染與相對濕度呈正關聯, 與風速和大氣壓呈負關聯。心藏 病患兒感染RSV的結果比沒有心藏病兒童更為嚴重, 包括更長住院 時間（ 4 天比 2 天， $\mathrm{P}<0.001$ ）、更高併發症發生率（28.6\%比9.8\%， $\mathrm{P}<0.001)$ 、更高深切治療部入住率 $(11.6 \%$ 比 $1.4 \%, \mathrm{P}<0.001)$ 和更 高呼吸機使用率 $(3.6 \%$ 比 $0.4 \%, \mathrm{P}=0.003)$ 。非心臟病患者的併發症 包括心肌炎和川崎氏病。本研究顯示心力衰竭、肺動脈高壓和先天性 心藏病相關的嚴重氣道異常可預測心藏病患兒RSV感染的嚴重性

結論：香港 RSV感染主要於春季和夏季發生, 感染率與氣象有 關。RSV感染給心臟病患兒帶來沉重疾病負擔, 故有需要為他們作出 RSV免疫預防的本地建議。

\section{Introduction}

Respiratory syncytial virus (RSV) infection poses a heavy disease burden in children worldwide. ${ }^{1,2}$ Haemodynamically significant congenital heart disease (hs-CHD) has been mainly studied and identified as a risk factor for severe RSV infection., ${ }^{3,4}$ National immunoprophylaxis policies for RSV in children have been adopted worldwide. ${ }^{5-11}$ In Hong Kong, under the Paediatric Coordinating Committee of the Hospital Authority, guidelines and government funding for RSV immunoprophylaxis for children with bronchopulmonary dysplasia of prematurity were established in 2012. ${ }^{12}$ However, no consensus has been reached regarding guidelines for RSV immunoprophylaxis for children with congenital or acquired heart disease (HD), because the epidemiology and impact of RSV infection on these patients have not been delineated in Hong Kong. ${ }^{13-16}$ It has been suggested that the high morbidity and mortality rates of RSV infection in children with hs-CHD observed during the prepalivizumab era ${ }^{3}$ are no longer applicable, owing to advances in healthcare. To widen the scope of the study regarding HD there is a need to conduct an updated local study regarding the epidemiology and impact of RSV infection on children with all types of HD, with the aim of providing evidence-based recommendations for RSV immunoprophylaxis.

\section{Methods}

\section{Study design}

Hong Kong has a population of 7.48 million, including a paediatric population (aged $\leq 18$ years) of approximately 1.1 million. Over $90 \%$ of in-patient service and nearly all tertiary service is provided by the public health system. There are 12 public hospitals providing approximately 1500 acute paediatric beds, of which 45 are paediatric intensive care beds; the total annual discharges and deaths are approximately 88500 . The present study was a multicentre retrospective case-control study of RSV infection in children in four hospitals with large paediatric departments, including 22 paediatric intensive care beds and approximately 630 acute paediatric beds, from 1 January 2013 to 31 December 2015.

\section{Recruitment criteria}

Paediatric patients were recruited using the Clinical Data Analysis and Reporting System electronic database of the Hong Kong Hospital Authority. The inclusion criteria were: (1) any discharge diagnosis of RSVinfection, includingbronchiolitis and pneumonia [International Classification of Diseases, Ninth Revision, codes: 079.6 (0), 466.0 (9), 466.11, 480.1]; and (2) laboratory confirmation of RSV infection from patients' nasopharyngeal or endotracheal secretions, either by immunofluorescent antigen staining ( $\mathrm{D}^{3}$ Ultra 8 DFA; Diagnostic Hybrids Inc, Athens $[\mathrm{OH}], \mathrm{US})$ or RNA detection by reverse transcriptase polymerase chain reaction (Xpert Xpress Flu/RSV; Cepheid, Sunnyvale [CA], US).

\section{Data collection}

Information was collected regarding epidemiologic characteristics, demographics, and clinical information (eg, laboratory and pharmacy data, preexisting co-morbidities, complications, reinfection, and intensive care unit [ICU] and ventilator requirements). Complications were defined as new secondary diagnosis related to RSV infection in a specific episode. Heart disease was defined as the presence of any active HD, including structural defects and cardiomyopathies. Patients who showed complete resolution of HD were considered normal. Diagnosis was confirmed by echocardiography, with or without cardiac catheterisation. Details of HD were retrieved, such as haemodynamic status, need for medication, and need for operation. One designated paediatrician from each hospital verified and retrieved information from the patients' paper records, if needed. The numbers of hospital admissions for acute respiratory infections in the same period were also retrieved from each hospital. Meteorological information was obtained from the electronic database of the Hong Kong Observatory. 


\section{Main outcomes}

First, the epidemiology of RSV infection and its association with meteorological conditions in the entire cohort was studied. Then patients were excluded if they had significant co-morbidities other than HD, including chronic lung disease, neuromuscular problems, and immunocompromised status, which are expected to increase the severity of RSV infection. ${ }^{17-19}$ Patients with social problems awaiting placement in the hospital causing undue prolonged hospital stay were also excluded. The remaining patients were then divided into heart disease (HD) and control (without any comorbidities) groups to compare the severity of RSV infection. Cardiac patients alone were analysed to identify cardiac predictors of severe outcome from RSV infection (Fig 1).

\section{Statistical analysis}

Statistical analysis was conducted using SPSS (Windows version 23.0; IBM Corp, Armonk [NY], US). Continuous data were tested for normality. There was a large difference in sample size between the HD and control groups; therefore, non-parametric tests were used to compare these groups: the MannWhitney $U$ test was used for univariate analysis of continuous data, and the Chi squared test or Fisher's exact test were used for categorical variables, where appropriate. The same statistical analyses were repeated using a smaller control group ( $1 / 10$ of the original size), which was obtained by generating an age- and sex-matched random sample from the original control group. This repeat analysis yielded similar results, which showed that the statistical tests used were acceptable despite the large discrepancy in sample size. Univariate and multivariate regression analyses were also performed. A backward variable selection method was used for model building. Results were considered statistically significant when $\mathrm{P} \leq 0.05$.

\section{Results}

\section{Epidemiology}

There were 3538 RSV-related hospital admissions in the four paediatric departments during the 3-year period, which constituted $11.8 \%$ of acute respiratory infection admissions to the four departments and $43 \%$ of all RSV admissions to public hospitals in Hong Kong. The age distribution of the admitted patients is shown in Table 1 . The RSV infections primarily affected children aged <5 years: $96.2 \%$ in the entire cohort and $97.3 \%$ in the HD group. Furthermore, RSV infections were most common in children aged $<1$ year: $44.6 \%$ in the entire cohort and $56.3 \%$ in the HD group. There was a mild male sex preponderance in the entire cohort, as well as in the HD group: male-to-female ratios of 1.32 and

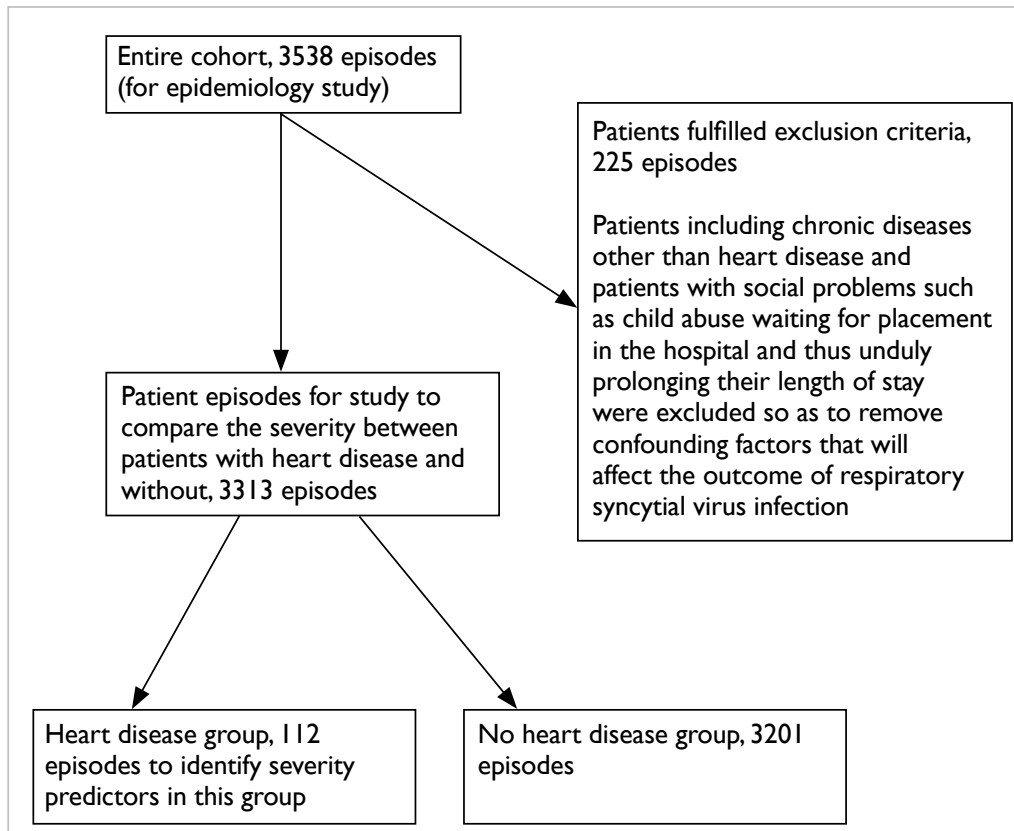

FIG I. Inclusion and exclusion criteria

TABLE I. Age distribution of the entire cohort of paediatric patients with respiratory syncytial virus infection, those with heart disease (heart disease group), and those without co-morbidities (control group)

\begin{tabular}{lccc}
\hline Age & $\begin{array}{c}\text { Entire cohort (3538 } \\
\text { episodes) }\end{array}$ & $\begin{array}{c}\text { Heart disease group } \\
\text { (112 episodes) }\end{array}$ & $\begin{array}{c}\text { Control group } \\
\text { (3201 episodes) }\end{array}$ \\
\hline$<1$ year & 1577 & 63 & 1439 \\
1 year & 765 & 21 & 695 \\
2 years & 633 & 16 & 584 \\
3 years & 338 & 8 & 312 \\
4 years & 92 & 1 & 82 \\
5 years & 45 & 2 & 35 \\
6-10 years & 61 & 1 & 40 \\
$>10$ years & 27 & 0 & 14 \\
\hline
\end{tabular}

1.29). The mortality rates were $0.14 \%(n=5)$ in the entire cohort and $0 \%$ in the HD group. All patients who died had an underlying chronic illness, such as congenital hereditary muscular dystrophy, spinal muscular atrophy, acute leukaemia, or asthma.

The aggregated monthly trend of RSV infection is shown in Figure 2. Most infections (87.7\% of those in the entire cohort and $91.1 \%$ of those in the HD group) occurred during the period from January to September, peaking from March to August (the spring and summer months). With respect to meteorological factors, bivariate correlation analysis of the entire cohort showed that the aggregated monthly RSV incidence had a statistically significant positive correlation with the monthly mean relative humidity $(r=0.71, \mathrm{P}=0.010)$ and statistically significant negative correlations with the monthly 
mean wind speed $(r=-0.80, \mathrm{P}=0.002)$ and monthly mean atmospheric pressure $(r=-0.62, \quad \mathrm{P}=0.032)$ [Table 2]. Backward linear regression revealed that only monthly mean wind speed was significantly and independently associated with monthly RSV incidence $(\mathrm{B}=-31.716,95 \%$ confidence interval $[\mathrm{CI}]=-48.61$ to $-14.82 ; \mathrm{P}=0.002)$.

\section{Impact of respiratory syncytial virus infection on children with heart disease}

Overall, 225 episodes were excluded because they involved patients who had co-morbidities other than HD. The HD group had 112 episodes involving 105 patients, while the control group had 3201 episodes involving 3155 patients. The demographic

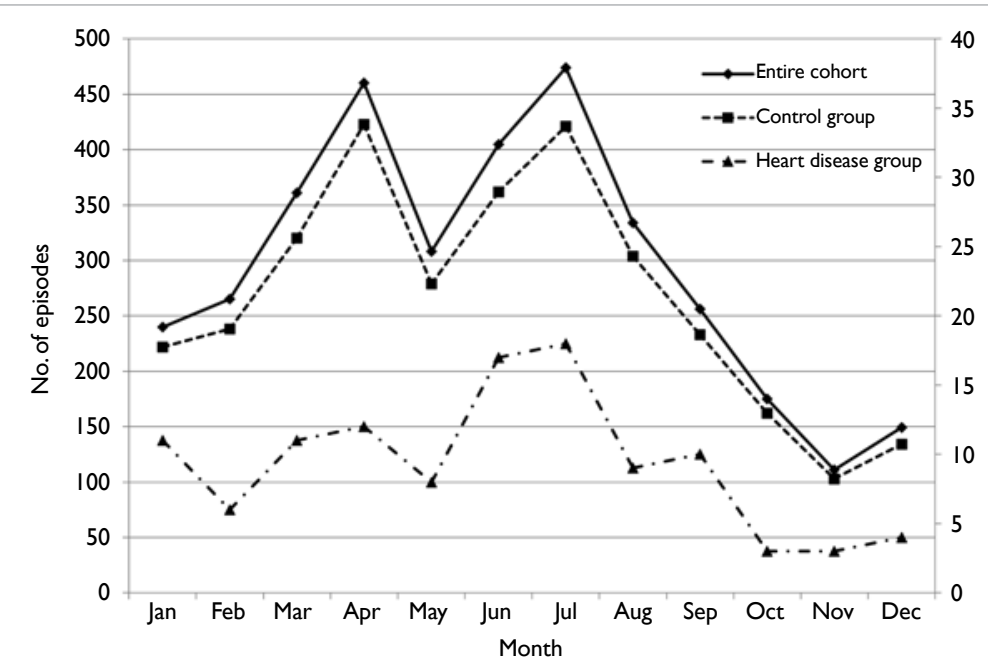

FIG 2. Aggregated monthly RSV-related hospitalisations among the entire cohort of paediatric patients with RSV (3538 episodes), those with heart disease (heart disease group, I 12 episodes), and those without co-morbidities (control group, 3201 episodes), from 2013 to $2015^{*}$

Abbreviation: RSV = respiratory syncytial virus

* Data for whole cohort/control groups and heart disease group are shown on the left and right y-axis, respectively and clinical details of both groups are depicted in Table 3. The HD and control groups had similar age distribution (median [interquartile range] $=0.9$ years [0.46-1.97 years] vs 1.19 years [0.45-2.4 years]; $\mathrm{P}=0.068$ ) and sex proportion (male preponderance of $56.3 \%$ vs $56.9 \%, \mathrm{P}=0.899)$. There was no statistically significant difference in mortality rate ( $0 \%$ in HD group vs $0.03 \%$ in control group; $\mathrm{P}=1$ ). Patient-based analysis revealed that the HD group had a higher RSV re-infection rate ( $>1$ episode in the study period) than the rate in the control group ( $7.6 \%$ vs $1.7 \%, \mathrm{P}<0.001)$. Respiratory syncytial virus infection was statistically significantly more severe in the HD group than in the control group in terms of the hospital length of stay (median $=4$ days $[3-6$ days] vs 2 days $[2-4$ days]; $\mathrm{P}<0.001)$, respiratory failure requiring respiratory support $(17.0 \%$ vs $5.1 \%$; $\mathrm{P}<0.001)$, requirement of ICU care $(11.6 \%$ vs $1.4 \%$, $\mathrm{P}<0.001)$, requirement of invasive or non-invasive mechanical ventilation $(3.6 \%$ vs $0.4 \%, \mathrm{P}=0.003)$, and occurrence of complications $(28.6 \%$ vs $9.8 \%$, $\mathrm{P}<0.001)$. Respiratory failure and dehydration were common complications in both groups. However, heart failure exacerbation $(n=13)$ and arrhythmia $(n=3)$ only occurred in the HD group, while febrile convulsion $(\mathrm{n}=96)$, acute myocarditis $(\mathrm{n}=2)$, and Kawasaki disease $(n=8)$ were only observed in the control group. There was no statistically significant difference between the two groups in terms of coinfection rate $(8.9 \%$ vs $7.8 \% ; \mathrm{P}=0.665)$. More than half of co-infections (55.4\%) were due to respiratory organisms: rhinovirus was most common, followed by adenovirus, Haemophilus influenzae, and Pneumococcus bacteria (Table 4).

\section{Predictors of severe outcome in cardiac patients}

In the HD group, 26 patients had a history of partial surgical repair of heart lesions, while nine others

TABLE 2. Correlations of meteorological factors with aggregate monthly incidence of hospitalisation for RSV infection in the entire cohort, 2013 to 2015

\begin{tabular}{|c|c|c|c|c|c|}
\hline \multirow[t]{2}{*}{ Meteorological factors $†$} & \multicolumn{2}{|c|}{ Correlation analysis } & \multicolumn{3}{|c|}{ Multivariate linear regression analysis* } \\
\hline & $\begin{array}{l}\text { Pearson correlation } \\
\text { coefficient }\end{array}$ & $P$ value & $\begin{array}{l}\text { Unstandardised coefficient, B } \\
\text { (95\% confidence interval) }\end{array}$ & $\begin{array}{l}\text { Standardised } \\
\text { coefficient, beta }\end{array}$ & $P$ value \\
\hline Monthly mean relative humidity & 0.71 & 0.010 & NS & NS & NS \\
\hline Monthly mean wind speed & -0.80 & 0.002 & $-31.716(-48.61$ to -14.82$)$ & -0.798 & 0.002 \\
\hline Monthly mean atmospheric pressure & -0.62 & 0.032 & NS & NS & NS \\
\hline Monthly mean temperature & 0.40 & 0.194 & NS & NS & NS \\
\hline Monthly total rainfall & 0.53 & 0.075 & NS & NS & NS \\
\hline Monthly mean amount of cloud & 0.50 & 0.076 & NS & NS & NS \\
\hline Monthly total bright sunshine & -0.15 & 0.639 & NS & NS & NS \\
\hline
\end{tabular}

Abbreviations: NS = not significant; RSV = respiratory syncytial virus

* $\mathrm{R}^{2}=0.636$

+ Meteorological data obtained from Climatological Information Service, Hong Kong Observatory 
TABLE 3. Comparison of epidemiology, mortality and morbidity of patients with and without heart disease who were hospitalised for RSV infection*

\begin{tabular}{|c|c|c|c|}
\hline & Heart disease group & Control group & $P$ value \\
\hline No. of RSV-related hospitalisations (headcount) & $112(105)$ & $3201(3155)$ & \\
\hline Age (years) & $0.9(0.46-1.97)$ & $1.19(0.45-2.4)$ & $0.068 \ddagger$ \\
\hline Sex, male & $63(56.3 \%)$ & $1820(56.9 \%)$ & $0.899 \S$ \\
\hline Mortality & 0 & $1(0.03 \%)$ & 1 \\
\hline$>1$ episodes of RSV infection $†$ & $8 / 105(7.6 \%)$ & $54 / 3155(1.7 \%)$ & $<0.001 \|$ \\
\hline Length of stay (days) & $4(3-6)$ & $2(2-4)$ & $<0.001 \ddagger$ \\
\hline $\begin{array}{l}\text { Respiratory failure (requiring oxygen therapy or } \\
\text { mechanical ventilation) }\end{array}$ & $19(17.0 \%)$ & $164(5.1 \%)$ & $<0.001 \S$ \\
\hline Requirement of ICU care & $13(11.6 \%)$ & $46(1.4 \%)$ & $<0.001 \|$ \\
\hline Requirement of mechanical ventilation & $4(3.6 \%)$ & $14(0.4 \%)$ & $0.003 \|$ \\
\hline Requirement of inotropes & $1(0.9 \%)$ & $6(0.2 \%)$ & $0.214 \|$ \\
\hline Occurrence of complications & $32(28.6 \%)$ & $314(9.8 \%)$ & $<0.001 \S$ \\
\hline Co-infection with other micro-organisms & $10(8.9 \%)$ & $250(7.8 \%)$ & $0.665 \S$ \\
\hline Co-infection with other respiratory micro-organisms & $7(6.3 \%)$ & $137(4.3 \%)$ & $0.338 \|$ \\
\hline
\end{tabular}

Abbreviations: ICU = intensive care unit; RSV = respiratory syncytial virus

* Data are shown as No. (\%) or median (interquartile range), unless otherwise specified

+ Some episodes of the same patients were excluded when exclusion criteria were met for those episodes, such as the presence of social problems

‡ Mann-Whitney $U$ test

$\S$ Pearson Chi squared test

II Fisher's exact test

required urgent cardiac surgery after recovery from RSV infection. Four cardiac risk factors were identified: (1) heart failure requiring medications $(n=26) ;(2)$ pulmonary hypertension $(n=7)$; (3) severe airway abnormalities associated with congenital heart disease (CHD) such as pulmonary artery sling $(n=6)$; and (4) cyanotic CHD $(n=1)$. Each patient could have multiple risk factors; 75 patients had no risk factors. Regression analyses involving age, sex, and the four risk factors were conducted to identify variables that could predict the severity of RSV infection. Backward multivariate linear regression showed that total hospital length of stay was positively and independently associated with heart failure $(\mathrm{B}=4.65,95 \% \mathrm{CI}=2.55-6.74, \mathrm{P}<0.001)$, pulmonary hypertension $(B=5.52,95 \% \mathrm{CI}=1.89-9.15$, $\mathrm{P}=0.003)$, and airway abnormalities $(\mathrm{B}=10.35,95 \%$ $\mathrm{CI}=6.44-14.25, \mathrm{P}<0.001)$. The ICU length of stay was positively and independently associated with airway abnormalities $(B=5.90,95 \% \mathrm{CI}=3.73-8.07, \mathrm{P}<0.001)$. Backward binary logistic regression revealed that the requirement of ICU care was positively associated with pulmonary hypertension (adjusted odds ratio $[\mathrm{aOR}]=20.67,95 \% \mathrm{CI}=3.74-114.21, \mathrm{P}=0.001)$ and airway abnormalities $(\mathrm{aOR}=15.50,95 \% \mathrm{CI}=2.56$ 93.84, $\mathrm{P}=0.003)$. Similarly, respiratory failure was positively associated with both pulmonary hypertension $\quad(\mathrm{aOR}=9.27, \quad 95 \% \quad \mathrm{CI}=1.41-61.05$, $\mathrm{P}=0.021)$ and airway abnormalities $(\mathrm{aOR}=11.21,95 \%$ $\mathrm{CI}=1.84-68.33, \mathrm{P}=0.009$ ) [Table 5].
TABLE 4. Co-infections with other micro-organisms in the heart disease and control groups $(n=3313)$

\begin{tabular}{llcc}
\hline Type of infection & Micro-organisms & No. & Infections, No. (\%) \\
\hline Respiratory infection & Rhinovirus & 56 & $144(4.3 \%)$ \\
& Adenovirus & 22 & \\
& Haemophilus influenzae & 17 & \\
& Pneumococcus & 16 & \\
& Influenza & 13 & \\
& Parainfluenza & 7 & \\
& Others & 13 & \\
\hline Gastroenteritis & Salmonella & 28 & \\
\hline & Norovirus & 21 & \\
\hline Rotal & Rotavirus & 5 & $19(0.57 \%)$ \\
\hline Urinary tract infection & Others & 3 & $40(1.2 \%)$ \\
\hline Miscellaneous & & & $260(7.8 \%)$ \\
\hline Total & & & \\
\hline & & & \\
\hline & & & \\
\hline
\end{tabular}

\section{Discussion}

To the best of our knowledge, this is the first study reviewing the epidemiology and impact of RSV infection on children with HD in Hong Kong. The representative sample in this study included $43 \%$ of all RSV-related hospitalisations in the public sector. 
TABLE 5. Potential predictors of severe outcome from RSV infection in patients with heart disease

\begin{tabular}{|c|c|c|c|c|c|c|c|c|}
\hline \multirow{3}{*}{$\begin{array}{l}\text { Potential severity } \\
\text { predictors }\end{array}$} & \multicolumn{4}{|c|}{ Multivariate linear regression } & \multicolumn{4}{|c|}{ Multivariate logistic regression } \\
\hline & \multicolumn{2}{|c|}{ Total hospital length of stay } & \multicolumn{2}{|c|}{ ICU length of stay } & \multicolumn{2}{|c|}{ Requirement of ICU care } & \multicolumn{2}{|c|}{$\begin{array}{l}\text { Occurrence of } \\
\text { respiratory failure }\end{array}$} \\
\hline & $\begin{array}{c}\text { Unstandardised } \\
\text { coefficient B } \\
(95 \% \mathrm{Cl})\end{array}$ & $P$ value & $\begin{array}{c}\text { Unstandardised } \\
\text { coefficient B } \\
(95 \% \mathrm{Cl})\end{array}$ & $\mathbf{P}$ value & $\begin{array}{l}\text { Adjusted odds } \\
\text { ratio }(95 \% \mathrm{CI})\end{array}$ & $P$ value & $\begin{array}{l}\text { Adjusted odds } \\
\text { ratio }(95 \% \mathrm{Cl})\end{array}$ & $P$ value \\
\hline Age & NS & NS & NS & NS & NS & NS & NS & NS \\
\hline Sex & NS & NS & NS & NS & NS & NS & NS & NS \\
\hline Heart failure & $4.65(2.55-6.74)$ & $<0.001$ & NS & NS & NS & NS & NS & NS \\
\hline Pulmonary hypertension & $5.52(1.89-9.15)$ & 0.003 & NS & NS & $20.67(3.74-114.21)$ & 0.001 & $9.27(1.41-61.05)$ & 0.021 \\
\hline $\begin{array}{l}\text { Severe airway abnormalities } \\
\text { related to CHD }\end{array}$ & 10.35 (6.44-14.25) & $<0.001$ & $5.90(3.73-8.07)$ & $<0.001$ & $15.50(2.56-93.84)$ & 0.003 & $11.21(1.84-68.33)$ & 0.009 \\
\hline Cyanotic heart disease & NS & NS & NS & NS & NS & NS & NS & NS \\
\hline
\end{tabular}

Abbreviations: $95 \% \mathrm{Cl}=$ 95\% confidence interval; CHD = congenital heart disease; ICU = intensive care unit; NS = not significant; RSV = respiratory syncytial virus

Respiratory infection due to RSV was common in children in Hong Kong, causing $11.8 \%$ of hospital admissions for acute respiratory infection; it was most common in children aged $<5$ years, similar to the findings of another study in Hong Kong (96.2\% vs $98.4 \%) .{ }^{13}$ However, the incidence of respiratory infection due to RSV in patients aged $<1$ year in the present study was lower than that in Western studies (44.6\% vs $75 \%-90 \%){ }^{2}$ This is potentially because babies in Hong Kong are typically cared for at home with the help of grandparents or domestic helpers, rather than attending nursery facilities. Coupled with the small number of children in most Hong Kong families, this may have reduced the rate of cross-infection. ${ }^{20}$ Male sex was identified as a risk factor for RSV-related hospitalisation, as in prior studies, but the male preponderance in this study was slightly lower than that of other studies $(1.32: 1$ vs 1.44-1.65:1). . $13,20-23^{2}$ The mortality rate of RSVrelated hospitalisation was extremely low (0.14\%), which was similar to the rates in local and worldwide studies $(0.15 \%-1 \%) .{ }^{2,13,15}$ Most deaths occurred in patients who had underlying chronic illnesses.

Although the seasonality of RSV infection in Hong Kong, a subtropical area, is not well-defined in the manner observed in temperate regions, there is a degree of seasonal variation. As in other studies from Hong Kong and Singapore, ${ }^{13-16,24}$ this study showed that RSV infection peaked in the humid spring and summer months, but was less common from October to December during the dry and windy season. Indeed, analysis of meteorological data showed that RSV infection was positively correlated with relative humidity and negatively correlated with both wind speed and atmospheric pressure. Relative humidity has been consistently associated with RSV infection rate in other studies. ${ }^{13,16,25}$ Notably, RSV in large particle aerosol form is more stable at higher humidity and may thus favour transmission. ${ }^{25}$ While temperature, rainfall, and sunlight were associated with RSV infection in previous studies, ${ }^{13,16,25}$ this study showed that wind speed was negatively associated with RSV infection. We presume that strong wind disturbs the stability of RSV in aerosol. We recommend that individuals who care for young children maintain a dry and well-ventilated environment to decrease the likelihood of crossinfection. In addition, this study highlighted the differences in RSV seasonality in Hong Kong, relative to other parts of Asia. Taiwan has two biennial peaks (spring and autumn), while Malaysia has a single peak infection period (September to December)..$^{22,23}$ Thus, local epidemiological and climatic data are pivotal in determining the appropriate timing for RSV immunoprophylaxis.

In this study, we included all types of HD, rather than $\mathrm{CHD}$ alone; notably, acquired $\mathrm{HD}$, such as cardiomyopathy, can increase vulnerability to RSV infection. ${ }^{26}$ The characteristics of RSV infection in cardiac patients have changed. First, the percentage of cardiac patients in this study was lower than that in prior studies (3.2\% vs $8 \%-16.4 \%) .{ }^{3,22,27-29}$ Second, the outcome of RSV infection in this study was less severe than that of prior studies with respect to the requirement of ICU care (11.6\% vs $30.4 \%-63 \%)$, requirement of mechanical ventilation $(3.6 \%$ vs $19 \%$ $24 \%$ ), and rate of mortality ( $0 \%$ vs $2.5 \%-37 \%) .3,22,27-$ 29 These differences may be related to the ongoing tendencies for economicand healthcare improvement; they may also be related to good antenatal ultrasound service, termination of pregnancies involving severe $\mathrm{CHD}$, and easy access to medical service in Hong Kong. However, as in other studies, children with HD in Hong Kong exhibit significantly more severe outcomes from RSV infection than do children without co-morbidity. ${ }^{15,22,26,29-31}$ 
In the present study, myocarditis and Kawasaki disease were complications of RSV infection in the non-cardiac group. These associations have not been extensively reported in prior studies, and further investigation is needed. The lack of these complications in the HD group may be explained by the much smaller sample size in that group (the HD group had 112 episodes involving 105 patients, while the control group had 3201 episodes involving 3155 patients). The rate of co-infection with other respiratory viruses in this study was low compared with that reported in a meta-analysis $(4.3 \%$ vs $\leq 50 \%)^{2}$; however, the findings were similar in that dual infection led to a more severe disease course and that rhinovirus was the most common coinfecting agent. Notably, adenovirus was the second most common agent in this study, whereas it was human bocavirus in the meta-analysis; the presence of this virus is not routinely assessed in Hong Kong.

Within the HD group, we identified three severity predictors for RSV infection, namely heart failure requiring medications, pulmonary hypertension, and severe airway abnormalities associated with CHD. The first two have been well described $3,22,26,27$ and were included in the American Academy of Pediatrics guideline for RSV prophylaxis ${ }^{11}$; severe airway abnormality associated with CHD has not been extensively investigated in previous studies of RSV infection. Pulmonary artery sling with tracheal stenosis is not easily identified during prenatal examinations and some affected patients remain undiagnosed for a few months after birth. The disease may first be identified during respiratory infection, such as RSV, and most patients exhibit severe courses of disease. In contrast to the findings of the Taiwanese study, ${ }^{32}$ we did not find cyanotic CHD to be a severity predictor. This was potentially because the number of such patients was very small in our series $(n=1)$. Indeed, the number of live births of patients with severe cyanotic CHD is decreasing in Hong Kong due to the high rate of termination of pregnancies involving the disease. The number of surviving patients with severe untreated cyanotic CHD is also small, as they either receive some form of surgical treatment or do not survive early infancy.

Early studies stressed the importance of hygiene and infection control for the prevention of RSV infection..$^{20}$ The IMpact-RSV study in the late 1990s led to the approval of palivizumab (a monoclonal antibody) for passive immunisation in the US in 1998 and in Europe in 1999 for children with chronic lung disease or prematurity. ${ }^{5,6,33}$ In 2003 , the use of palivizumab in the US was extended to children with hs-CHD (heart failure, pulmonary hypertension, and cyanotic CHD) who were aged $\leq 2$ years.,34 Comparable national guidelines have been gradually adopted globally, including in Asian countries (Japan in 2006 and Korea in 2009). ${ }^{8,9}$ In temperate regions with a distinct RSV season length of approximately 6 months, the typical palivizumab regimen is monthly intramuscular injection at $15 \mathrm{mg} / \mathrm{kg} /$ dose during the RSV season, with a maximum of five doses. However, in subtropical regions without a clear RSV season, monthly injection may be necessary for the entire year, which is costly. In 2011, a study in Taiwan showed that a protocol of six consecutive monthly doses in at-risk children, beginning when the risk was initially detected in the first year of life, was also effective.$^{10}$ Currently, the American Academy of Pediatrics limits routine RSV immunoprophylaxis to children who have acyanotic CHD with heart failure or pulmonary hypertension in the first year of life. ${ }^{11}$ In the United Kingdom, children who have cyanotic or acyanotic CHD with significant co-morbidities are recommended to receive RSV immunoprophylaxis until age 2 years. ${ }^{35}$ In 2017, however, an international steering committee broadened the indications to children with unoperated hs-CHD or symptomatic airway abnormalities who were aged $\leq 2$ years, as well as children with cardiomyopathy requiring treatment who were aged $\leq 1$ year. $^{36}$ A CanadianItalian group questioned whether children with hs-CHD need higher doses of immunoprophylaxis because of their increased inherent risks. ${ }^{37}$ Numerous studies have shown the safety and efficacy of RSV immunoprophylaxis and its long-term benefit in children with HD. ${ }^{6,30,38-40}$ It is therefore imperative to establish similar guidelines in Hong Kong. In accordance with local experience regarding bronchopulmonary dysplasia in premature babies, ${ }^{12}$ an RSV immunoprophylaxis scheme administered monthly for five doses, beginning in the first year of life, should be considered in children with HD who exhibit severity predictors such as heart failure, pulmonary hypertension, and/or severe airway abnormality related to CHD. The optimal timing for immunoprophylaxis may be during the local peak of infection, from March to August.

\section{Limitations of this study}

Because this was a retrospective hospital-based study, the incidence of RSV respiratory infection may have been underestimated; however, we presume that only patients with relatively mild disease were potentially omitted. As in all retrospective reviews, this study did not use a pre-defined protocol for management and clinical documentation. This limitation was partially addressed by analysing objective clinical details which are relatively standard and easily retrievable through electronic means. We also collected outpatient follow-up records when necessary to provide additional information regarding co-morbidities. However, instances of re-infection before and after the study period were not assessed due to technical limitations, which is not ideal. 


\section{Conclusions}

Respiratory syncytial virus infections are common in Hong Kong, and the incidence peaks from March to August; prevalence is greatest in children aged $<1$ year, and there is a mild male preponderance. Infection is favoured by high relative humidity, low wind speed, and low atmospheric pressure. Heart disease, both congenital and acquired, is a distinct risk factor for severe RSV infection in terms of hospital length of stay, reinfection, complication, respiratory failure, and the requirements for ICU care and mechanical ventilation. In Hong Kong, an RSV immunoprophylaxis scheme administered monthly for five doses, beginning during spring and summer in the first year of life, should be considered in children with HD who exhibit any of the following severity predictors: heart failure, pulmonary hypertension, and severe airway abnormalities associated with CHD.

\section{Author contributions}

All authors contributed to the concept of study, acquisition and analysis of data. SH Lee and KL Hon wrote the article and had critical revision for important intellectual content. All authors had full access to the data, contributed to the study, approved the final version for publication, and take responsibility for its accuracy and integrity.

\section{Acknowledgement}

We thank Ms Kathy YC Tsang of Prince of Wales Hospital who provided expert and continuous statistical support for this study.

\section{Conflicts of interest}

All authors have disclosed no conflicts of interest.

\section{Declaration}

The results from this research have been presented, in part, at the following conferences:

1. The first phase of this research involving two hospitals on the impact of respiratory syncytial virus (RSV) infection in children with heart disease was presented in the 2nd Asian RSV Expert Forum, Singapore, 24 October 2016.

2. The preliminary data of this research involving four hospitals on the epidemiology and impact of RSV infection in children with heart disease were presented in: (a) "RSV infection in Hong Kong Children" forum organised by the Hong Kong Society of Paediatric Cardiology, 17 January 2017 and (b) the Working Group on Use of Palivizumab for RSV Infection Prophylaxis in Children under Hospital Authority Paediatric COC, 30 August 2017.

3. A modified abstract was selected as poster presentation in the Joint Annual Scientific Meeting of Hong Kong College of Paediatricians, 28 September 2019 (with prior permission by Editor-in-Chief of the Hong Kong Medical Journal).

\section{Funding/support}

This research received no specific grant from any funding agency in the public, commercial, or not-for-profit sectors.

\section{Ethics approval}

This study was approved by the Research Ethics Committees of the Hospital Authority of Hong Kong (Ref KC/KE-160122/ER-2). There is no ethical concern and waiver for obtaining consent was approved by the Cluster Research Ethics Committees of the Hospital Authority of Hong Kong. All procedures performed in this study involving human participants were in accordance with the ethical standards of the institutional and/or national research committee and with the 1964 Helsinki declaration and its later amendments or comparable ethical standards.

\section{References}

1. Nair H, Nokes DJ, Gessner BD, et al. Global burden of acute lower respiratory infections due to respiratory syncytial virus in young children: a systematic review and meta-analysis. Lancet 2010;375:1545-55.

2. Bont L, Checchia PA, Fauroux B, et al. Defining the epidemiology and burden of severe respiratory syncytial virus infection among infants and children in Western countries. Infect Dis Ther 2016;5:271-98.

3. MacDonald NE, Hall CB, Suffin SC, Alexson C, Harris PJ, Manning JA. Respiratory syncytial viral infection in infants with congenital heart disease. N Engl J Med 1982;307:397400.

4. Welliver RC. Review of epidemiology and clinical risk factors for severe respiratory syncytial virus (RSV) infection. J Pediatr 2003;143(5 Suppl):S112-7.

5. American Academy of Pediatrics: Committee on Infectious Diseases and Committee on Fetus and Newborn. Prevention of respiratory syncytial virus infections: indications for the use of palivizumab and update on the use of RSV-IGIV. Pediatrics 1998;102:1211-6.

6. Simoes EA. Immunoprophylaxis of respiratory syncytial virus: global experience. Respir Res 2002;3 Suppl 1:S2633.

7. American Academy of Pediatrics: Committee on Infectious Diseases and Committee on Fetus and Newborn. Policy Statement: Revised indications for the use of palivizumab and respiratory syncytial virus immune globulin intravenous for the prevention of respiratory syncytial virus infections. Pediatrics 2003;112(6 Pt 1):1442-6.

8. Nakazawa M, Saji T, Ichida F, Oyama K, Harada K, Kusuda S. Guidelines for the use of palivizumab in infants and young children with congenital heart disease. Pediatr Int 2006;48:190-3.

9. Kim NK, Choi JY. Respiratory syncytial virus prevention in children with congenital heart disease: who and how? Korean J Pediatr 2011;54:197-200.

10. Chi $\mathrm{H}$, Hsu $\mathrm{CH}$, Chang JH, et al. A novel six consecutive monthly doses of palivizumab prophylaxis protocol for the prevention of respiratory syncytial virus infection in highrisk preterm infants in Taiwan. PLoS One 2014;9:e100981.

11. American Academy of Pediatrics: Committee on Infectious Diseases; American Academy of Pediatrics Bronchiolitis Guidelines Committee. Updated guidance for palivizumab prophylaxis among infants and young children at increased risk of hospitalization for respiratory syncytial virus infection. Pediatrics 2014;134:415-20.

12. Lee SR, Kwok KL, Ng DK, Hon KL. Palivizumab for infants $<29$ weeks in Hong Kong without a clear-cut season for respiratory syncytial virus infection-a cost-effectiveness analysis. J Trop Pediatr 2018;64:418-25. 
13. Chan PK, Sung RY, Fung KS, et al. Epidemiology of respiratory syncytial virus infection among paediatric patients in Hong Kong: seasonality and disease impact. Epidemiol Infect 1999;123:257-62.

14. Hon KL, Leung TF, Cheng WY, et al. Respiratory syncytial virus morbidity, premorbid factors, seasonality, and implications for prophylaxis. J Crit Care 2012;27:464-8.

15. Leung TF, Lam DS, Miu TY, et al. Epidemiology and risk factors for severe respiratory syncytial virus infections requiring pediatric intensive care admission in Hong Kong children. Infection 2014;42:343-50.

16. Chan PK, Tam WW, Lee TC, et al. Hospitalization incidence, mortality, and seasonality of common respiratory viruses over a period of 15 years in a developed subtropical city. Medicine (Baltimore) 2015;94:e2024.

17. Hall CB, Powell KR, MacDonald NE, et al. Respiratory syncytial viral infection in children with compromised immune function. N Engl J Med 1986;315:77-81.

18. Groothuis JR, Gutierrez KM, Lauer BA. Respiratory syncytialvirusinfection in children with bronchopulmonary dysplasia. Pediatrics 1988;82:199-203.

19. Wilkesmann A, Ammann RA, Schildgen O, et al. Hospitalized children with respiratory syncytial virus infection and neuromuscular impairment face an increased risk of a complicated course. Pediatr Infect Dis J 2007;26:485-91.

20. Simoes EA. Environmental and demographic risk factors for respiratory syncytial virus lower respiratory tract disease. J Pediatr 2003;143(5 Suppl):S118-26.

21. Purcell K, Fergie J. Driscoll Children's Hospital respiratory syncytial virus database: risk factors, treatment and hospital course in 3308 infants and young children, 1991 to 2002. Pediatr Infect Dis J 2004;23:418-23.

22. Lee JT, Chang LY, Wang LC, et al. Epidemiology of respiratory syncytial virus infection in northern Taiwan, 2001-2005-seasonality, clinical characteristics, and disease burden. J Microbiol Immunol Infect 2007;40:293301.

23. Khor CS, Sam IC, Hooi PS, Quek KF, Chan YF. Epidemiology and seasonality of respiratory viral infections in hospitalized children in Kuala Lumpur, Malaysia: a retrospective study of 27 years. BMC Pediatr 2012;12:32.

24. Chew FT, Doraisingham S, Ling AE, Kumarasinghe G, Lee BW. Seasonal trends of viral respiratory tract infections in the tropics. Epidemiol Infect 1998;121:121-8.

25. Welliver R. The relationship of meteorological conditions to the epidemic activity of respiratory syncytial virus. Paediatr Respir Rev 2009;10 Suppl 1:6-8.

26. Kristensen K, Stensballe LG, Bjerre J, et al. Risk factors for respiratory syncytial virus hospitalisation in children with heart disease. Arch Dis Child 2009;94:785-9.

27. Moler FW, Khan AS, Meliones JN, Custer JR, Palmisano J, Shope TC. Respiratory syncytial virus morbidity and mortality estimates in congenital heart disease patients: a recent experience. Crit Care Med 1992;20:1406-13.

28. Wang EE, Law BJ, Stephens D. Pediatric Investigators Collaborative Network on Infections in Canada (PICNIC): prospective study of risk factors and outcomes in patients hospitalized with respiratory syncytial viral lower respiratory tract infection. J Pediatr 1995;126:212-9.

29. Jung JW. Respiratory syncytial virus infection in children with congenital heart disease: global data and interim results of Korean RSV-CHD survey. Korean J Pediatr 2011;54:192-6.

30. Chang RK, Chen AY. Impact of palivizumab on RSV hospitalizations for children with hemodynamically significant congenital heart disease. Pediatr Cardiol 2010;31:90-5.

31. Chu PY, Hornik CP, Li JS, Campbell MJ, Hill KD. Respiratory syncytial virus hospitalisation trends in children with haemodynamically significant heart disease, 1997-2012. Cardiol Young 2017;27:16-25.

32. Chiu SN, Shao PL, Chen HC, et al. Risk of respiratory syncytial virus infection in cyanotic congenital heart disease in a subtropical area. J Pediatr 2016;171:25-30.e1.

33. The IMpact-RSV Study Group. Palivizumab, a humanized respiratory syncytial virus monoclonal antibody, reduces hospitalization from respiratory syncytial virus infection in high-risk infants. Pediatrics 1998;102(3 Pt 1):531-7.

34. Feltes TF, Cabalka AK, Meissner HC, et al. Palivizumab prophylaxis reduces hospitalization due to respiratory syncytial virus in young children with hemodynamically significant congenital heart disease. J Pediatr 2003;143:53240.

35. UK Government. The Green Book. Immunisation against infectious disease. Available from https://webarchive. nationalarchives.gov.uk/20130104181824/https://www. wp.dh.gov.uk/immunisation/files/2012/09/Green-Bookupdated-040113.pdf. Accessed 17 Jul 2019.

36. Tulloh RM, Medrano-Lopez C, Checchia PA, et al. CHD and respiratory syncytial virus: global expert exchange recommendations. Cardiol Young 2017;27:1504-21.

37. Manzoni P, Paes B, Lanctôt KL, et al. Outcomes of infants receiving palivizumab prophylaxis for respiratory syncytial virus in Canada and Italy: An international, prospective cohort study. Pediatr Infect Dis J 2017;36:2-8.

38. Cohen SA, Zanni R, Cohen A, et al. Palivizumab use in subjects with congenital heart disease: results from the 2000-2004 Palivizumab Outcomes Registry. Pediatr Cardiol 2008;29:382-7.

39. Resch B, Michel-Behnke I. Respiratory syncytial virus infections in infants and children with congenital heart disease: update on the evidence of prevention with palivizumab. Curr Opin Cardiol 2013;28:85-91.

40. Wegzyn C, Toh LK, Notario G, et al. Safety and effectiveness of palivizumab in children at high risk of serious disease due to respiratory syncytial virus infection: a systematic review. Infect Dis Ther 2014;3:133-58. 